\title{
PENINGKATAN KEMAMPUAN BACA TULIS AL-QUR'AN MELALUI METODE SCAFFOLDING PADA SISWA KELAS V MI TERPADU AD-DIMYATI BANDUNG
}

\author{
Oleh: Shalahudin Ismail \\ Mahasiswa Pascasarjana UIN Sunan Gunung Djati Bandung 2016 \\ email: kosmakc2016@gmail.com
}

\begin{abstract}
As the Word of Allah, the Qur'an is a holy book that is basically as a guide and guide of man to achieve prosperity and happiness of the world and the hereafter. But in fact many students can not read and write al-Qur'an. One of the contributing factors behind this is that educators tend to focus solely on conventional learning methods. This study aims to test whether there is an increase in literacy ability of Al-Qur'an students of class V MI Integrated Ad-Dimyati Bandung after using scaffolding method. This research uses quasi-experiment one grouf pretest posttest method. The conclusion in this research that scaffolding method is very systematic and effective in improving literacy ability of Qur'an student of class $V M I$.
\end{abstract}

Key Word :

Read Write Al-Qur'an, Method Scaffolding

\begin{abstract}
Abstrak : Sebagai kalam Allah, al-Qur'an adalah kitab suci yang pada dasarnya sebagai pedoman dan pembimbing manusia untuk mencapai kemakmuran dan kebahagiaan dunia dan akhirat. Namun pada kenyataanya banyak siswa yang tidak bisa membaca dan menulis al-Qur'an. Salah satu faktor penyebab di balik ini adalah pendidik cenderung hanya berfokus pada metode pembelajaran konvensioanal. Penelitian ini bertujuan untuk menguji apakah ada peningkatan kemampuan baca tulis al-Qur'an siswa kelas V MI Terpadu Ad-Dimyati Bandung setelah menggunakan metode scaffolding. Penelitian ini menggunakan metode quasi-experimen one grouf pretest posttest. Kesimpulan dalam penelitian ini bahwa metode scaffolding sangat sistematis dan efektif dalam meningkatkan kemampuan baca tulis al-Qur'an siswa kelas V MI.
\end{abstract}

Kata Kunci :

Baca Tulis Al-Qur'an, Metode Scaffolding

\section{PENDAHULUAN}

Al-Qur'an adalah kitab suci terakhir yang diturunkan kepada Nabi Muhammad saw. Bahasa yang digunakan merupakan bahasa asli setempat saat itu, yaitu bahasa Arab yang dikenal mempunyai tingkat kesusatraan yang tinggi. Bahasa Arab tergolong bahasa asing, oleh karena itu dibutuhkan strategi dan metode yang inovatif dalam upaya mempelajari bahasa tersebut. Dalam surah at-Taubah ayat 122 disebutkan:

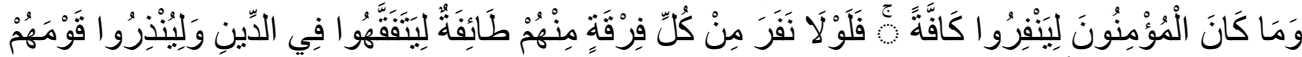

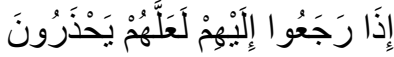

Arti"nya :"Mengapa tidak pergi dari tiap-tiap golongan di antara mereka beberapa orang untuk memperdalam pengetahuan mereka tentang agama dan untuk memberi peringatan kepada kaumnya apabila mereka telah kembali kepadanya, supaya mereka itu dapat menjaga dirinya. (Hasan, 2012, h. 206)"

Pendalaman ilmu agama harus dibarengi dengan kajian kitab suci agama tersebut. Sebab, di dalamnya terkandung banyak referensi, solusi serta undang-undang 
dalam menjalani kehidupannya selaku hamba. Salah satu tahap awal dalam menguasai dan memahami kandungan al-Qur'an adalah melalui kemampuan membaca dan menulisnya. Kemahiran ini ditandai dengan penguasaan huruf hijaiyah yang dilanjutkan dengan ilmu tajwid. Tujuan kemahiran ini adalah agar bacaan al-Qur'an sesuai dengan tempat keluarnya huruf (Makharijul Huruf) dan porsi panjang pendek mad-nya. Pada dasarnya al-Qur'an itu mudah untuk dipelajari dan mengkaji makna yang terkandung di dalamnya. Allah SWT, telah memberikan stimulus terhadap para pembelajar al-Qur'an melalui firman-Nya yang diulang sebanyak 4 kali dalam surah al-Qomar ayat 17, 22, 32, dan 40 sebagai berikut:

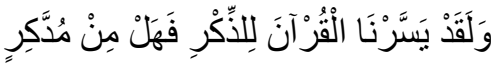

Artinya : Dan sungguh telah Kami mudahkan al-Qur'an untuk peringatan. Maka adakah orang yang mau mengambil pelajaran."

Realitas umat Islam sekarang ini amat memprihatinkan jika dilihat dari sisi kemampuan baca tulis al-Qur'an. Realita ini pula yang terjadi pada sebagian siswa MI Terpadu Ad-Dimyati Bandung, sebuah sekolah yang sebagian besar mempelajari ilmuilmu agama. Banyak faktor yang menyebabkan baca tulis al-Qur'an mereka rendah, diantaranya:

1. Pendidik cenderung hanya berfokus pada model pembelajaran konvensional

2. Suasana kelas hanya berpusat pada pendidik sehingga siswa menjadi pasif

3. Siswa hanya mencatat dan mendengar apa yang dikatakan guru dan menyebabkan tidak adanya interaksi dalam proses belajar mengajar, sehingga siswa merasa bosan dan jenuh dalam belajar baca tulis al-Qur'an.

4. Masih rendahnya motivasi siswa. Hal ini disebabkan kurangnya pemahaman maksud dan tujuan membaca dan menulis al-Qur'an, bahkan pelajaran ini bagi mereka kurang menarik karena dianggap menjenuhkan dan membosankan.

5. Faktor lingkungan dan masyarakat juga sering menjadi kendala terhadap kemampuan membaca dan menulis al-Qur'an. Sebagian orang tua masih memandang dan bangga apabila putranya berhasil dalam pelajaran umum.

Pada jenjang pendidikan dasar, membaca dan menulis ayat-ayat al-Qur'an merupakan kompetensi dasar yang mesti dicapai. Saat ini telah berkembang berbagai model pembelajaran baca tulis al-Qur'an, namun belum sepenuhnya mampu menunjang pencapaian kedua kompetensi tersebut secara efektif. Siswa sering kali sudah fasih dalam membaca al-Qur'an, namun tidak demikian dalam hal menulis. Untuk itu diperlukan solusi atas permasalahan tersebut, yaitu dengan menerapkan pembelajaran aktif (active learning) yang menuntun adanya model pembelajaran penunjang, diantaranya adalah model pembelajaran scaffolding yang menekankan pada interaksi dalam proses belajar. Dengan pertolongan orang dewasa, siswa dapat melakukan dan memahami lebih banyak hal dibandingkan dengan siswa yang belajar sendiri. 
Pembelajaran terjadi saat siswa bekerja menangani tugas-tugas yang belum dipelajari namun berada dalam zone of proximal development mereka. Menurut Vygotsky, Zone of Proximal Development (ZPD) adalah jarak antara tingkat perkembangan sesungguhnya yang ditunjukkan dalam kemampuan pemecaham masalah secara mandiri dan tingkat kemampuan potensial yang ditunjukkan dalam kemampuan pemecahan masalah di bawah bimbingan orang dewasa atau temans ebaya yang lebih mampu.

Dengan latar belakang di atas, maka diujikan suatu metode pembelajaran untuk meningkatkan kemampuan baca tulis al-Qur'an yang disebut metode pembelajaran scaffolding. Penelitian ini berfokus pada bagaimana penerapan metode scaffolding dalam pembelajaran baca tulis al-Qur'an dan apakah ada peningkatan kemampuan membaca dan menulis al-Qur'an setelah menggunakan metode scaffolding.

Kemampuan berasal dari kata "mampu" yang berarti kuasa, dapat, atau sanggup melakukan (Hoetomo, 2005, h. 332). dalam kamus psikologi dijelaskan bahwa kemampuan yaitu istilah umum yang dikaitkan dengan kemampuan atau potensi dalam menguasai suatu keahlian ataupun pemikiran itu sendiri. Adapun membaca menurut Qurais Shihab diambil dari kata menghimpun, yang dari kata inilah muncul beragam makna seperti menyampaikan, menela'ah, mendalami, meneliti, mengetahui ciri sesuatu, dan membaca baik teks tertulis maupun tidak tertulis. Dalam ulumul Qur'an dikenal dengan istilah "Qira' at". Artinya bacaan yang disandarkan kepada salah seorang imam dari qurra yang tujuh, sepuluh atau empat belas ( Gus, 2010, h. 28). Keterampilan membaca al-Qur'an diklasifikasikan menjadi dua tahap, yaitu tahap pemula dan tahap lanjut. Tahap pemula berorientasi pada pembelajaran membaca yakni membunyikan lambang-lambang huruf hijaiyyah. Kalimat pendek dalam bahasa Arab hingga membaca ayat-ayat pendek al-Qur'an dan belum sampai pada pemberian makna. Berbeda dengan membaca tahap lanjut berorientasi pada membaca pemahaman terhadap konteks yang dibaca.

Membaca al-Qur'an bernilai ibadah, oleh karenanya sebagaimana ibadah terdapat rukun yang harus dipenuhi dalam membaca al-Qur'an. Ada tiga rukun dalam membaca al-Qur'an, yaitu: 1) Sesuai dengan kaidah dan aturan bahasa Arab, 2) Sesuai dengan tulisan yang terdapat dalam Mushaf Usmani, 3) Ketersambungan sanad dengan ulama qurra yang masyhur. ${ }^{2}$ Secara spesifik, tujuan membaca al-Qur'an adalah sebagai berikut:

1. Siswa dapat membaca kitab Allah dengan mantap, baik dari segi ketepatan harakat, saktat (tempat-tempat berhenti) menyembunyikan huruf-huruf yang sesuai dengan makhrajnya dan persepsi maknanya.

2. Siswa mengerti makna al-Qur'an dan berkesan dalam jiwanya

3. Siswa mampu menumbuhkan rasa haru, khusyu, dan tenang jiwanya serta takut kepada Allah

4. Siswa terbiasa membaca pada mushaf dan memperkenalkan istilah-istilah yang tertulis baik yang waqaf, mad dan idgham. 
Selain membaca, menulis juga merupakan suatu keterampilan yang digunakan untuk berkomunikasi baik secara langsung ataupun tidak langsung. Menulis huruf Arab itu tidak mudah seperti yang dibayangkan, karena bahasa adalah sebuah logika murni yang dimulai dari huruf yang tunggal sampai tahap derivasi kepada huruf yang lain. Yang dimaksud kemampuan menulis adalah kemampuan yang dapat diaplikasikan setelah kemampuan membaca. Diantara keterampilan-keterampilan berbahasa, menulis adalah keterampilan tertinggi dari empat keterampilan berbahasa. Keterampilan menulis terpusat pada tulisan yang benar dan memperbaiki khot. ${ }^{3}$ Secara umum tujuan kemampuan menulis ada dua, yaitu memperkuat struktur dan kata yang telah dikuasai oleh siswa dan juga meneruskan kemampuan siswa sampai terbiasa dalam inovasi berbahasa Arab. ${ }^{4}$ Untuk itu diperlukan suatu metode yang tepat dalam mengajarkan baca tulis al-Qur'an.

Model pembelajaran scaffolding pertama kali diperkenalkan di akhir tahun 1950an oleh Jerome Bruner, seorang psikolog kognitif. Dia menggunakan istilah itu untuk menggambarkan anak-anak muda dalam akuisi bahasa. Anak-anak pertama kali mulai belajar berbicara melalui bantuan orang tua mereka. Secara naluriah anak-anak telah memiliki struktur untuk belajar berbahasa. Scaffolding merupakan interaksi antara orang-orang dewasa dan anak-anak yang memungkinkan untuk melaksanakan sesuatu di luar usaha mandirinya. Menurut Vygotsky, scaffolding adalah suatu teknik pemberian bantuan oleh orang-orang yang ahli (guru atau teman sesama peserta didik yang lebih pandai) sepanjang pembelajaran agar peserta didik beranjak dari zona aktual menuju zona potensial Lebih lanjut Vygotsky menyatakan ide penting mengenai scaffolding yaitu pemberian bantuan kepada peserta didik selama tahap-tahap awal perkembangannya dan mengurangi bantuan tersebut serta memberikan kesempatan kepada peserta didik untuk mengambil alih tanggungjawab yang semakin besar setelah mereka dapat melakukannya (Trianto, 2011, h.27). Zona antara tingkat perkembangan aktual siswa dan tingkat perkembangan potensial siswa disebut zona perkembangan terdekat. Zona perkembangan terdekat adalah tingkat perkembangan sedikit di atas tingkat perkembangan saat ini. Pembentukan (scaffolding) mendominasi pembentukan mental siswa dimana guru dapat berfungsi sebagai pengingat dan pendukung siswa dalam mendapatkan mental yang lebih tinggi dalam menyelesaikan masalah yang dihadapi siswa.

Metode scaffolding merupakan penyediaan tingkat dukungan yang berubah-ubah dalam sesi pembelajaran. Dengan individu yang lebih teramlpil, seorang guru atau teman sebaya yang lebih pandai dan dapat memberikan bimbingan agar sesuai dengan prestasi siswa yang lain. Penerapan metode scaffolding dalam pembelajaran baca tulis al-Qur'an dapat dilakukan dengan cara sebagai berikut: 
a. Guru memberikan contoh dengan membaca dan menulis salah satu surah dalam al-Quran kepada siswa, dan siswa diminta mengamati dan mengidentifikasi surah tersebut.

b. Guru meminta siswa menjelaskan tentang cara-cara membaca dan menulis surah al-Qur'an tersebut sesuai dengan pengetahuan mereka

c. Dari hasil tanya jawab dengan siswa, guru mengambil kesimpulan mengenai cara membaca dan menulis surah tersebut

d. Guru mengidentifikasi siswa berdasarkan tingkat kognitifnya, atau yang memiliki zone of proximal development yang relatif sama. Siswa dengan tingkat kognitifnya jauh di bawah rata-rata akan lebih diperhatikan

e. Siswa dikelompokkan secara acak, dengan maksud supaya siswa yang memiliki zone of proximal development di atas rata-rata kelas membantu temannya yang memiliki zone of proximal development di bawah rata-rata kelas. Jadi, tidak hanya guru yang berperan dalam menjembatani siswa dalam menyelesikan masalah, tetapi teman sebayanya juga.

f. Guru berkeliling memantau pekerjaan siswa. Jika siswa kesulitan dalam membaca dan menulis surah al-Qur'an tersebut, maka guru atau temannya membantu siswa yang kesulitan dalam membaca dan menulis surah al-Qur'an tersebut.

g. Siswa membacakan surah al-Qur'an serta mengumpulkan tulisannya.

h. Guru menanyakan tentang kesulitan yang dialami siswa selama membaca dan menulis al-Qur'an untuk menentukan zone of proximal development pada pertemuan selanjutnya.

\section{METODOLOGI PENELITIAN}

Metode penelitian yang digunakan dalam penelitian ini adalah kuasi eksperimen (quasi experiment design) dengan menggunakan desain nonequivalent control group design. Dinamai demikian karena dalam pembagian sampel penelitian kedalam kelompok eksperimen dan kontrol dan tidak dilakukan secara acak atau tidak melalui proses random assignment, tetapi ditentukan berdasarkan kelas yang telah ada. Metode eksperimen ini dipilih dengan dasar untuk menguji pengaruh satu atau lebih variabel terhadap variabel lain atau hubungan sebab akibat dari satu atau beberapa variabel.

Dalam penelitian, terdapat dua variabel utama yakni variabel bebas atau variabel prediktor yang sering diberi notasi $\mathrm{X}$ yang diduga menyebabkan atau memberikan suatu efek terhadap peristiwa lain. Sedangkan variabel terikat atau respons sering disebut notasi Y, yakni variabel yang ditimbulkan atau efek dari variabel bebas (Sudjana, 2007, h. 12). Penelitian ini menggunakan sumber data primer yakni sumber data yang diperoleh langsung sebagai hasil pengumpulan data oleh peneliti yang berupa tes kemampuan baca tulis al-Qur'an. Populasi dalam penelitian ini adalah seluruh siswa kelas V MI Terpadu Ad-Dimyati Bandung dengan sampel diambil dari siswa yang masuk kelompok eksperimen dan kontrol. 


\section{HASIL PENELITIAN DAN PEMBAHASAN}

Data dari penelitian ini adalah kuantitatif yang diperoleh dari hasil belajar baca tulis al-Qur'an siswa kelas V MI melalui pretest dan posttest. Untuk memperoleh data tersebut, perlu dilakukan serangkaian penghitungan sebagai berikut:

Uji normalitas dilakukan untuk menguji apakah variabel berdistribusi normal atau tidak. Uji normalitas menggunakan rumus Shapiro-Wilk dengan program SPSS 16.0 for Windows. Untuk mengetahui normal dan tidaknya adalah jika sig. > 0,05, maka dikatakan normal dan jika sig. $<0,05$, dapat dikatakan tidak normal. Hasil perhitungan yang diperoleh nilai pretest 0,908 dan posttest 0,364 . Keduanya lebih besar dari 0,05, maka data berdistribusi normal.

Setelah diketahui tingkat kenormalan data, maka selanjutnya dilakukan uji homogenitas. Uji homogenitas digunakan untuk mengetahui tingkat kesamaan varians antara dua kelompok. Untuk menerima atau menolak hipotesis dengan membandingkan harga sig pada levene's statistik dengan probalitas 0,05 (sig. $>0,05$ ). Hasil uji homogenitas dapat diketahui nilai pretest 0,367 dan posttest 0,101 . Dari hasil perhitungan, harga signifikansi data pretest dan posttest lebih besar dari 0,05, maka dapat disimpulkan bahwa data dalam penelitian ini memiliki varians yang homogen.

Setelah diketahui data tersebut berdistribusi normal dan homogen, maka uji hipotesis yang dilakukan dengan menggunakan uji t dengan bantuan program SPSS. 16.0 for Windows. Adapun hipotesis dalam penelitian ini adalah sebagai berikut:

a) Hipotesis $\mathrm{Nol}\left(\mathrm{H}_{0}: \mu_{1}=\mu_{2}\right)$, tidak terdapat perbedaan peningkatan kemampuan baca tulis al-Qur'an siswa kelas V sebelum dan sesudah menggunakan metode scaffolding.

b) Hipotesis Satu $\left(\left(\mathrm{H}_{1}: \mu_{1} \neq \mu_{2}\right)\right.$, terdapat perbedaan peningkatan kemampuan baca tulis al-Qur'an siswa kelas $\mathrm{V}$ sebelum dan sesudah menggunakan metode scaffolding.

Adapun hasil uji t pretest dn posttes ditunjukkan pada tabel berikut:

Hasil Uji T Pretest dan Posttest Kemampuan BTQ

\begin{tabular}{|l|l|l|l|c|}
\hline Hasil & Rata-rata & Thitung & T tabel & P \\
\cline { 1 - 2 } Pretest & $\mathbf{6 3 , 2 3}$ & $\mathbf{2} 9.863$ & 2.021 & \multirow{2}{*}{0,000} \\
\hline Posttest & $\mathbf{8 0 , 4 0}$ & & & \\
\hline
\end{tabular}

Berdasarkan tabel di atas, didapatkan nilai rata-rata pretest sebesar 63,23 dan rata-rata nilai posttest sebesar 80,40 sehingga mengalami peningkatan sebesar 17,17 . Di dapatkan juga thitung >ttabel pada taraf signifikansi $5 \%(9.863>2,021)$ dan mempunyai nilai $\mathrm{p}<0,05$ yang berarti dapat disimpulkan terdapat peningkatan secara signifikan kemampuan baca tulis al-Qur'an siswa kelas V MI. Adapun grafik peningkatan kemampuan pretest dan posttest baca tulis al-Qur'an siswa kelas V MI sebagai berikut: 


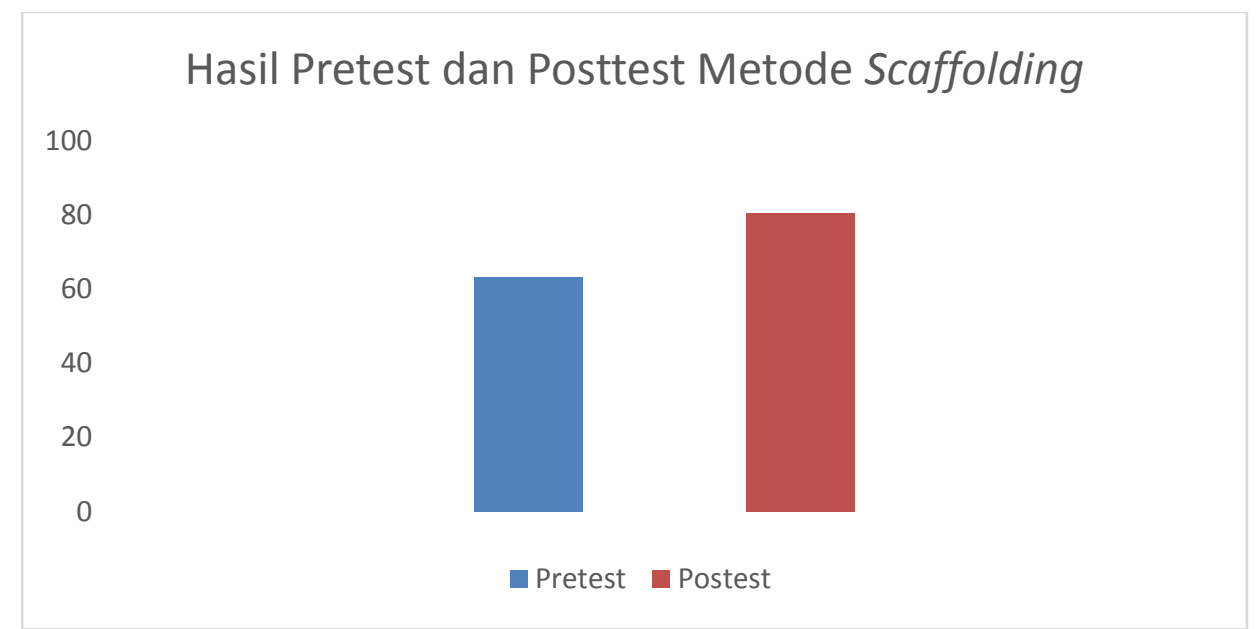

Rumusan masalah pertama adalah bagaimana penggunaan metode scaffolding dalam pembelajaran baca tulis al-Qur'an. Tahapan penerapan metode scaffolding adalah:

a) Perencanaan Pembelajaran

Sebelum pelaksanaan pembelajaran baca tulis al-Qur'an, peneliti menerapkan perencanaan pembelajaran yang terdiri atas kompetensi dasar yang akan dicapai, tema yang akan disampaikan, metode pembelajaran, waktu dan jumlah pertemuan serta alat evaluasi yang digunakan. Kompetensi dasar disesuaikan dengan tema yang akan disampaikan, metode yang digunakan sesuai dengan penelitian ini yaitu metode scaffolding, waktu yang digunakan 45 menit selama 8 pertemuan dan alat evaluasi berupa pretest (tes awal) dan posttest (tes akhir).

b) Kegiatan Awal Pembelajaran

1) Menyapa siswa

2) Menyiapkan fokus belajar

3) Siswa ditest (pretest) untuk mengetahui kemampuan membaca dan menulis al-Qur'an

4) Mengecek hasil belajar untuk menentukan zona of proximal development

5) Membagi kelompok berdasarkan level perkembangan awal yang dimiliki siswa yang diketahui dari hasil pretest siswa

c) Kegiatan Inti Pembelajaran

1) Menjabarkan tugas-tugas

2) Menyajikan tugas belajar secara berjenjang dengan tetap memberikan penjelasan, peringatan, dorongan, serta penguaraian masalah ke dalam langkah pemecahan

3) Mengurangi dukungan atau bantuan dan memberikan waktu kepada siswa untuk menyelesaikan tugas tersebut secara mandiri.

d) Kegiatan Penutup

1) Mengecek hasil belajar yang telah dicapai oleh siswa

2) Menutup pelajaran dan tetap memberikan arahan kepada siswa agar tergerak ke arah kemandirian dan pengaturan diri dalam belajar.

1. Pembahasan Rumusan Masalah Kedua 
Rumusan masalah kedua adalah apakah ada peningkatan kemampuan membaca dan menulis al-Qur'an setelah menggunakan metode scaffolding. Keberhasilan proses pembelajaran tidak terlepas dari kemampuan pendidik dalam mengembangkan model pembelajaran, yang berorientasi pada peningkatan intensitas keterlibatan peserta didik secara efektif dalam proses pembelajaran. Penggunaan metode pembelajaran yang tepat pada dasarnya bertujuan menciptakan kondisi pembelajaran yang efektif dan menyenangkan bagi peserta didik sehingga dapat meningkatkan kemampuan Baca Tulis Al-Quran yang optimal. Setelah diterapkannya metode scaffolding kemampuan baca tulis al-Qur'an siswa semakin meningkat. Hasil posttest yang telah diberikan, diperoleh nilai rata-rata kemampuan baca tulis al-Qur'an siswa sebesar 80,40 dan diinterpretasikan ke dalam skala 100 termasuk katagori sangat baik karena berada dalam interval 81-85.

\section{SIMPULAN}

Metode pembelajaran scaffolding sesuai dengan teori Vygostky dalam pembelajaran, yaitu: a) menghendaki setting kelas berbentuk pembelajaran kooperatif antar siswa, sehingga siswa dapat bertinteraksi di sekitar tugas-tugas dan saling memunculkan strategi-strategi pemecahan masalah dalam zona of proximal development, b) diterapkannya metode scaffolding dalam pembelajaran agar siswa semakin lama semakin bertanggung jawab terhadap pembelajarannya sendiri. Setelah penggunaan metode scaffolding terdapat peningkatan kemampuan baca tulis al-Qur'an siswa dengan hasil nilai rata-rata posttest 80,40 .

\section{DAFTAR PUSTAKA}

Abdulllatif, Model Pembelajaran Scaffolding. (online). http://repository.upi.edu (3 Februari 2018).

Abdul Qodir, Muhammad, 1981, Thuruqu Ta'limi At-tarbiyah Al-Islamiyah, Kairo: Maktabah Al-Nahdoh Al-Misyriyyah

Basri, Hasan, 2012, Terjemah Al-Qur'an Al-Mubarrok, Bandung: Al-Hira

Gus Arifin dan Suhendri Abu Faqih, 2010, Al-Qur'an Sang Mahkota Cahaya, Jakarta: Elek Media Komputindo

Hamid, Abdul, 2008, Media Pembelajaran Bahasa Arab, Malang:UIN Malang Press, 2008

Hoetomo, 2005, Kamus Lengkap Bahasa Indonesia, Surabaya: PT. Mitra Pelajar

Ibrahim, Muhammad Jaramy, 2001, Mu'jam Ulum Al-Qur'an, Damaskus: Darul Qolam

Jum'ah, Ali, 1425 H, Ahlkamu At-Tilawah Wa At-Tajwid Al-Muyassarah, Riyadh: Darul Nafais,

Kartini Kartono dan Dali Dula, 1987, Kamus psikologi Pendidikan, Bandung: CV. Pionerjaya

Najar, Philip, 1969, Arabic Without Teacher, Beirut: Dar Al Ilm Lilmalayin

N. Sudjana dan Ibrahim, 2007, Penelitian dan Penilaian Pendidikan, Bandung: Sinar Baru Algesindo 
Ratnawati Mamin, Penerapan Model Pembelajaran Scaffolding Pada Pokok Bahasan

Sistem Periodik Unsur" Jurnal Chemical, Vol 2, 55-60

Shihab, Quraish, 1998, Mukjizat Al-Qur'an, Bandung:Mizan

Supardi, Perbandingan Metode Membaca Al-Qur'an Bagi Pebelajar Pemula Di

TKA/TPQ Kelurahan Bareng Malang dalam Jurnal Penelitian Keislaman, $1 / 12 / 2004$

Suyono \& Harianto, 2016, Belajar Dan Pembelajaran, Bandung: PT. Remaja Rosdakarya 2016

Trianto, 2011, Mendesain Model Pembelajaran Inovatif Progresif, Edisi Ke-4, Jakarta: Kencana

Yamin, Martinis, 2011, Paradigma baru Pembelajaran, Jakarta:Gaung Persada 